\title{
A CRYSTALLIZATION MODEL FOR PERIDOTITIC DIAMOND INCLUSION SPINELS.
}

Daniels, Leon R.M.*

Dept. Geochemistry, University of Cape Town, Rondebosch 7700, South Africa.

*Present address: Geocontracts Botswana (Pty) Ltd, Private Bag 00140, Gaberone, Botswana.

Spinel, together with olivine, is the most common diamond inclusion in Yakutia(1) and at some southern African occurrences (e.g. Dokolwayo). It has been commonly found to coexist in diamondiferous xenoliths(2) and diamonds with olivine, orthopyroxene, Glo garnets and rarely with diopside, zircon and graphite(1-5). In both southern Africa and Yakutia similar compositional characteristics have been observed within the spinels (Table 1).

\begin{tabular}{|l|c|c|}
\hline \multicolumn{2}{|c|}{ TABLE 1 - DIAMOND INCLUSION SPINELS } \\
\hline $\begin{array}{c}\text { OXIDE } \\
(\text { wt\%) }\end{array}$ & $\begin{array}{c}\text { YAKUTIA (1) } \\
(\mathrm{n}=720)\end{array}$ & $\begin{array}{c}\text { S. AFRICA } \\
(\mathrm{n}=134)\end{array}$ \\
\hline $\mathrm{TiO}_{2}$ & $<0.7$ & $<0.7$ \\
$\mathrm{Al}_{2} \mathrm{O}_{3}$ & $3.5-7.5$ & $2.77-13.9$ \\
$\mathrm{Cr}_{2} \mathrm{O}_{3}$ & $62-67 *$ & $57.9-68.5$ \\
$\mathrm{FeO}^{\mathrm{MgO}}$ & $12-19 *$ & $4.17-16.4$ \\
& $11-15.5$ & $11.1-18.7$ \\
\hline
\end{tabular}

* Total Fe as Feo

Calculated equilibrium temperatures at $50 \mathrm{kbar}$ for the southern African diamonds with spinel inclusions suggest subsolidus temperatures which is consistent with the temperatures calculated for diamonds from this sub-region containing silicate phases. Calculated $\mathrm{fO}_{2}$ 's at $50 \mathrm{kbar}$ suggest oxygen fugacities between $\mathrm{WM}$ and $\mathrm{IW}$.

The coexistence of the diamond inclusion-type spinels with G10 garnets suggest a common paragenesis within a subcalcic chromium-rich harzburgitic environment. It is suggested that the key to determining the paragenesis of the spinels lies in establishing the origin of the Glo garnets. In addition to the subsolidus equilibrium temperatures calculated for diamonds containing G10 garnets, the most significant characteristic of these garnets is a depletion in $\mathrm{Ti}, \mathrm{Fe}, \mathrm{Ca}$, $\mathrm{Y}, \mathrm{Zr}, \mathrm{Ga}$ and $\mathrm{Zn}$ which is accompanied by an enrichment in $\mathrm{Cr}$, Mg and LREE's (6). A model of subsolidus crystallization is proposed.

The extraction of komatiitic or basaltic melts from a chondritic mantle at $2000^{\circ} \mathrm{C}$ and 50-70 kbar leaves a dry spinel-harzburgite residue depleted in $\mathrm{Ca}, \mathrm{Ti}, \mathrm{Y}, \mathrm{Zr}, \mathrm{Ca}$ and $\mathrm{Zn}$, and which is resistant to large scale melting. The olivines in the residue are forsteritic. At these temperatures and pressures the residual orthopyroxenes are $\mathrm{Al}_{2} \mathrm{O}_{3}$ and $\mathrm{Cr}_{2} \mathrm{O}_{3}$ enriched with low $\mathrm{Al}_{2} \mathrm{O}_{3} / \mathrm{Cr}_{2} \mathrm{O}_{3}$ ratios ( $\mathrm{Cr}$, $\left.\pm{ }^{1}\right), \mathrm{Ti}$ and $\mathrm{Ca}-$ depleted and contain a significant component 
of dissolved garnet. Based on the behaviour of chromium and titanium in silicate melts, the spinels may be $\mathrm{Cr}_{2} \mathrm{O}_{3}$ (>55wt\%) and $\mathrm{TiO}_{2}$ (average $>.07$ wt\%) rich. Vertical subduction, driven by the stacking of successive extrusions of komatiites and Archaean ocean floor basalts(7), results in advective thickening. LREE's, alkalis and carbon volatiles fluxing from the base of the descending slab, consisting of an undepleted sub-tectospheric mantle, metasomatises the harzburgitic residue ${ }^{(8)}$. In the absence of garnet the LREE's will, in preference to olivine and spinel, partition into the residual orthopyroxene. The carbon volatiles remain in solution.

On cooling from $2000{ }^{\circ} \mathrm{C}$ at which the komatiite melts are extracted to a steady state geothermal temperature of $1200{ }^{\circ} \mathrm{C}$ the orthopyroxene exsolves its garnet component. The major element composition of the exsolved garnet will be dependent on the composition of the residual orthopyroxene immediately after the extraction of the komatiite melts. The $\mathrm{Cr}-$ and $\mathrm{Mg}-$ enriched nature of the unexsolved orthopyroxene will favour the formation of $\mathrm{Mg}_{3} \mathrm{Cr}_{2} \mathrm{Si}_{3} \mathrm{O}_{12}$ in the exsolving garnet which, together with the depletion of the $\mathrm{FeO}, \mathrm{CaO}$ and $\mathrm{TiO}_{2}$, is consistent with major element compositional characteristics of G10 garnets. The LREE's partition from the orthopyroxenes preferentially into the garnet and consequently enrich the GI0's in LREE's.

The exsolution of Glo garnets from residual orthopyroxenes will progressively deplete $\mathrm{Al}_{2} \mathrm{O}_{3}$ in the pyroxene and the $\mathrm{Cr}$ in the exsolving garnet will gradually increase. Although the knorringite molecule in the garnet allows for greater solubility of the $\mathrm{Cr}$ in the garnet, the exsolution of spinels will be favoured at low $\mathrm{Cr}^{*}$ in the orthopyroxene. The predicted low $\mathrm{Cr}^{*}$ and $\mathrm{TiO}_{2}$-depleted composition of the residual komatiite orthopyroxenes will favour the exsolution of $\mathrm{TiO}_{2}$-poor $\mathrm{Cr}$-rich spinels together with the exsolution of Glo garnets. The presence of both G10 garnets and Cr-rich spinels, depleted in $\mathrm{TiO}_{2}$, in diamonds, xenoliths and the concentrate of diamondiferous kimberlites is consistent with the model above.

Subcalcic Glo garnets at Dokolwayo have $\mathrm{Cr}^{*}>1.00$. The exsolution of these garnets from the residual orthopyroxenes would deplete $A l$ in the residual pyroxene while Cr-enrichment occurs. Spinel exsolving from the orthopyroxene will

therefore become increasingly $\mathrm{Cr}$-rich. This may result in zonation patterns within the spinels exhibiting increasing $\mathrm{Cr}_{2} \mathrm{O}_{3}$ contents from centre to edge. Approximately fifty percent of the Dokolwayo concentrate spinels are compositionally similar to the diamond inclusion spinels and are characterized by $\mathrm{TiO}_{2} / \mathrm{Al}_{2} \mathrm{O}_{3}<0.2$. These spinels commonly exhibit zonation patterns consistent with the model above. It should be noted that the Dokolwayo concentrate spinels with $\mathrm{Al}_{2} \mathrm{O}_{3} / \mathrm{TiO}_{2}>0.2$ show no significant evidence of $\mathrm{Cr}_{2} \mathrm{O}_{3}$ zoning.

Calculated $\mathrm{fO}_{2}$ conditions suggest that the dominant carbon volatile species is $\mathrm{CH}_{4}$. At the reigning $\mathrm{T}, \mathrm{P}$ and $\mathrm{fO}_{2}$ conditions diamond crystallizes from the $\mathrm{CH}_{4}$ either through fractionation or oxidation of $\mathrm{CH}_{4}$. Mass balancing exercises show that olivine and a small amount of orthopyroxene, depleted of garnet component, also exsolves from original $\mathrm{Al}, \mathrm{Cr}$-enriched orthopyroxene. Because diamond crystallization and the process of exsolution occur simultaneously, the 
diamonds may occlude the exsolved minerals. The syngenetic relationship between diamonds and their primary inclusions suggests that the processes of exsolution and diamond crystallization occur simultaneously.

\section{References}

(1) Sobolev, N.V. et al. (1989). Chrome spinels coexisting with Yakutian diamonds. 28th Int. Geol. Cong. Wash., Ext. Abstr., Workshop on Diamonds, 105-108.

(2) Sobolev, N.V. et al. (1984). Xenoliths of diamond-bearing peridotites in kimberlites and the problem of diamond origin. Geol. Geofiz., 25, 63-80.

(3) Daniels, L.R.M. and Gurney, J.J. (1989). The chemistry of the garnets, chromites and diamond inclusions of the Dokolwayo kimberlite, Kingdom of Swaziland. In: Ross, J., Jaques, A.L., Ferguson, J., Green D.H., O'Reilly, S.Y., Danchin, R.V., Janse, A.J.A., Eds., Kimberlites and Related Rocks, Volume 2: Their Mantle/Crust Setting, Diamonds and Diamond Exploration, GSA Spec. Publ. No 14, Blackwell Scientific Publications, 1012-1021.

(4) Gurney J.J. et al. (1979). Silicate and oxide inclusions in diamonds from the Finsch kimberlite pipe. In: Boyd, F.R. and Meyer, H.O.A., Eds., Kimberlites, Diatremes and Diamonds, Their Geology, Petrology and Geochemistry. A.G.U., Washington, $1-15$.

(5) Gurney, J.J. et al. (1984). Minerals associated with diamonds from the Roberts Victor Mine. In: Kornprobst, J., Ed., Kimberlites II: Their Mantle and Crust-mantle relationships. Develop. in Petrology 11B, Elsevier, Amsterdam, $25-32$.

(6) Richardson, S.H. et al. (1984). Origin of diamonds in old enriched mantle. Nature, 310, 198-202.

(7) De Wit, M.J. and Tredoux, M. (1988). PGE in the $3.5 \mathrm{Ga}$ Jamestown Ophiolite Complex, Barberton Greenstone Belt, with implications for PGE distribution in simatic lithosphere. In: Pritchard, H.M., Potts, P.J., Bowles, J.F.W. and Cribb, S.J., Eds., Geo-Platinum $87,319-341$.

(8) Jordan, T.H. (1988). Structure and formation of the continental tectosphere. J. Petrol. 29, 11-37. 